\title{
Organized Farmers Towards Chickpea Seed Self-Sufficiency in Bundelkhand Region of India
}

\author{
Uma Sah, S. K. Chaturvedi, G. P. Dixit, N. P. Singh, \\ and P. Gaur
}

\section{Abstract}

Smallholder partner farmers under TL-III project were organized into four registered Farmers' Seed Societies for addressing the challenge of constrained availability of quality seed of improved chickpea varieties in Bundelkhand region of Uttar Pradesh state, India. These seed societies formed in Banda, Hamirpur and Chitrakoot districts contributed towards strengthening the formal seed system of chickpea by contributing 21.8 tons of chickpea seed (FS/TL) of recommended varieties (kabuli: Ujjawal, Shubhra; Desi: JG 14, JG 16 and JAKI 9218) and marketed it to institutionalized seed chains. More than 1500 partner farmers directly received the improved seed through farmers 'seed societies while 1788 non-partner farmers received it indirectly through social networks. The interventions boosted chickpea productivity from 0.78 to $1.19 \mathrm{t} / \mathrm{ha}$ in the project villages. The efforts of the farmers' societies to strengthen the informal seed system through farmer-to-farmer horizontal diffusion resulted in area enhancement under the introduced chickpea varieties up to $68 \%$ in the project villages while putting in place a system for supply of improved chickpea seed which can be replicated in other districts in India.

\section{Keywords}

Farmers society $\cdot$ Chickpea $\cdot$ Seed self-sufficiency $\cdot$ Bundelkhand region $\cdot$ India

U. Sah $(\bowtie) \cdot$ S. K. Chaturvedi · G. P. Dixit · N. P. Singh

ICAR-Indian Institute of Pulses Research, Kanpur, India

P. Gaur

International Crops Research Institute for the Semi-Arid Tropics (ICRISAT),

Patancheru, India 


\subsection{Antecedent}

Chickpea is an important pulse crop of India that occupies about 10.75 million hectares and contributes 11.23 million tones to the national pulse basket. It is primarily cultivated as a rainfed crop with limited external inputs. Bundelkhand region of Uttar Pradesh state in central India is a traditionally important chickpea-growing region (416,007 ha) that produces about 148,408 tons of chickpea. Spanning over 7.1 million hectares in the central semi-arid plateau, the region is drought frequented and represents one of the poorest regions of the country. Chickpea crop holds a prominent position in all the major cropping sequence, especially in the marginalized production situations, followed in region. In water constrained situations, chickpea crop is grown under rainfed mono-cropped conditions.

Poor seed replacement and low productivity levels, high incidence of pod borer and root disease coupled with several abiotic stresses limit the average chickpea productivity in the region to $400 \mathrm{~kg} / \mathrm{ha}$, against the national average $(1037 \mathrm{~kg} / \mathrm{ha})$. Smallholder farmers of the region often cite poor quality of seed as a major issue restraining the chickpea productivity level (Dixit et al. 2019).

Improving farmers' access to quality seeds of chickpea in this rainfed-dominated ecology is a challenge. Chickpea seed sector in the region is dominated by public sector agencies that have limited coverage and often the delivery mechanisms are complicated to be availed by smallholders. The farmers lacked access to new high yielding, diseases resistant chickpea varieties. As a consequence, smallholder farmers operating in the region continue to use farm produce of non-descript varieties as seed across, for all the major pulse crops especially chickpea crop that demands a higher seed rate for sowing (70-80 kg/ha). Farmers often exchange home grown seeds with apparently better yielding varieties available within their informal social networks including fellow farmers, friends and relatives. These factors have direct bearing on the chickpea productivity figures in the region (Srivastava et al. 2017).

For addressing the challenge of constrained availability of quality seed of improved chickpea varieties, partner farmers under TL-III project were organized into four formal groups as registered farmers' seed societies in Banda, Hamirpur and Chitrakoot districts in Bundelkhand region of Uttar Pradesh state of India. The innovation platforms were established with the following specific objectives: (1) to enhance farmers' knowledge related to seed production, processing and storage of chickpea crop for ensuring seed self-sufficiency at village level; (2) to promote diffusion of seed production technologies among farmers of the region; (3) to enhance the production of chickpea through dissemination of recommended and farmerpreferred varieties in the region; (4) to enhance chickpea production and consumption for overcoming protein malnutrition in the region; (5) to encourage scientific cultivation of chickpea crop in the region. 


\subsection{Establishment of the Platform}

The progressive partner farmers of TL-III project villages of Hamirpur, Chitrakoot and Banda districts in Bundelkhand region were encouraged and facilitated to form village level formal farmers' seed societies. Smallholder farmers in groups of 11 to 13 members each were organized as a Farmers' Society under Society Registration act no 21, 1860, Uttar Pradesh Government, India. The four farmers' seed societies that were formed included Khurahand Beej Vikas Samiti (12 members) in Banda district, Kusmara Beej Vikas Samiti (11 members) in Hamirpur district, Kalla Beej Vikas Samiti (12 members) and Baglai Beej Vikas Samiti (13 members) in Chitrakoot district of Bundelkhand region of Uttar Pradesh state, India.

A series of sensitization meeting were held with partner farmers in the project villages wherein they were briefed about the benefits of organizing themselves, organizational structure, the functioning and governance, membership fee registration process and related aspects. The farmers were also informed about the expected responsibility of the societies in complementing chickpea seed supply chain in their respective region. The partner farmers who volunteered to be a part of the society were supported for electing the office bearers of the society. The societies were also facilitated in developing the profile document of the society and in registration as formal farmers' seed societies.

\subsection{Composition, Roles and Responsibilities of the Platform Members}

The farmers' seed societies were registered with primary mandate of diffusion of seed production technologies for ensuring enhanced seed availability at the regional level. Special emphasis was given to pulse crops in these efforts. The members of the society elected the office bearers that included President, Vice President, Secretary and Treasurer (executive of the society) for five years tenure. The members of these seed societies were expected to formally meet to discuss on agenda related to functioning of the society. The executive and the general body in each society had well specified roles and responsibilities. Researchers and project staff from ICAR-IIPR facilitated the farmers' societies and were mainly responsible for advisory role. The formal seed system supported the farmers' societies in capacity enhancement in aspects related to chickpea seed production.

\subsection{Platform Activities}

The four formal seed societies were provided knowledge support on chickpea seed production technologies under TL-III project. In addition, these societies were provided higher yielding and root rot tolerant improved chickpea varieties (Kabuli: Shubhra, Ujjawal; Desi: JG-16, JG 14, RVG 203, RVG 202, JAKI 9218). These societies further engaged in chickpea seed production at village level through the 
member farmers and other who volunteered. This effort led to strengthening the formal as well informal seed chain of chickpea in the region as well as it contributed towards developing village level entrepreneurial activities. The activities undertaken by the farmers' seed societies included:

The executive body of the seed societies arranged seed of recommended chickpea varieties from ICAR-Institute of Pulses Research (ICAR-IIPR), Kanpur, India for initiating the seed production (FS/TL) in their districts. Further, members of the executive received training on seed production technologies at ICAR-IIPR and diffused the learning to other farmers who participated in the seed production programme at village level.

The farmers' seed societies were responsible for decisions related to selection of member farmers and fields for chickpea seed production. This involved ensuring recommended isolation distance in seed production plots. The executive of the society facilitated the ICAR-IIPR seed team and Uttar Pradesh State Seed Certification Agency in seed certification in their respective villages.

After harvest, produced seed was sorted, cleaned and graded under supervision of executive of the seed societies to ensure seed quality. The seed was then aggregated and marketed. Arrangement of pooled transportation facility on shared basis for carrying the seed to the selling platform was also a function of the executive.

The platforms also facilitated horizontal diffusion of introduced improved chickpea varieties through social networks in the respective districts. The research staff monitored the seed plots under guidance of researchers from ICAR-IIPR.

\subsection{Facilitation of Platform Activities, Including Meetings}

The platform activities were primarily carried out by the office bearers of farmers' seed societies with support from the field level staff of TL-III project posted at the district level. The societies held meeting periodically for discussion on agenda items with the members. The decision-making processes were carried out in a participatory manner with due consensus. The meetings of members of the farmers' societies with scientists and project team of TL-III project were also facilitated by the executive of the respective societies.

\subsection{Achievements of the Platform}

The seed societies developed linkages with formal agencies like ICAR-IIPR, Kanpur and Uttar Pradesh State Seed Certification Agency. ICAR-Indian Institute of Pulse Research, Kanpur provided the needed technological backstopping to these societies for chickpea seed production. The farmers' seed societies contributed towards strengthening the seed system of chickpea in the targeted districts. During 2015-16 to 2017-18, the farmers societies produced 21.8 tons of chickpea seed (FS/ TL) of recommended varieties (kabuli: Ujjawal, Shubhra; Desi: JG 14, JG 16 and JAKI 9218) and marketed it to institutionalized government seed chains. 
The farmers societies formed in three districts also developed horizontal linkages with each other for exchange of learning and seed. Farmer-to-farmer informal diffusion of improved seed of chickpea was facilitated by the societies in their respective districts, which contributed in supporting the farmers' seed system.

The farmers' seed societies coordinated the capacity enhancement programmes (17) organized by ICAR-IIPR, Kanpur for the partner farmers engaged in chickpea seed production at village level in the targeted districts. The programmes were conducted at institute as well as at village level. The executive also facilitated application of the learning of these programmes in real field conditions and helped them realize higher productivity.

With the purpose of supporting the partner farmers through real-time agroadvisories, the members of the seed societies were linked to the mobile based voice advisory service of ICAR-IIPR, Kanpur 'Dalhan Sandesh' wherein they received customized advisories on chickpea crop.

Partnership based efforts were made during 2015-2019 under Tropical LegumesIII project to increase quality seed availability of newer varieties locally to small holders in the project villages through the farmers societies. About 58.3 tons seed of improved chickpea varieties (Kabuli: Shubhra, Ujjawal; Desi: JG 14, JAKI 9218, RVG 202, JG 16, RVG 203) was infused into the seed system in Banda, Hamirpur and Chitrakoot districts.

For identification of farmer-preferred varieties of chickpea crop, On-farm participatory varietal selection trials (102) were conducted with inclusion of improved chickpea varieties (Kabuli: Shubhra, Ujjawal; Desi: RVG 202, JG 16, RVG 203, JG-14, JG-16) along with advanced breeding lines, viz. IPC 04-01, IPC 04-98, IPC 5-62, IPC 6-77 in the region. For rapid varietal diffusion of identified varieties, seed packs of 6-8 kg each were provided to partner farmers (1129). Large-scale participatory demonstrations (293) for purpose of showcasing the disease resistant improved chickpea varieties in farmers' fields were conducted in eight project villages.

Partner farmers' preferences for offered varietal options varied with existing agricultural production situations. In general, chickpea is mostly grown as a rainfed crop on the residual moisture in the region and, therefore, farmers have the preference for varieties of shorter duration. In Banda district, farmers preferred short duration varieties JG 16 and JG 14 as these varieties fitted well in dominant paddychickpea cropping sequence being followed in the district. JAKI 9218 and Ujjawal varieties were preferred varieties for irrigated conditions, while JG 14 was preferred by partner farmers of rainfed situations in Hamirpur district. Smallholder farmers preferred JG 16 and JG 14 varieties for cultivation in Chitrakoot districts. 


\subsubsection{Achievements in the Areas of Access to Improved Seed and Other Inputs}

\subsubsection{Varieties Used by Farmers Before Membership and Access to Quality Seed}

The smallholder farmers operating in the targeted districts primarily resorted to use of farm saved produce as seed for chickpea crop before the project interventions were initiated. The primarily farmers used seed of non-descript varieties or their mixture for raising chickpea crop. However, they practiced exchanging chickpea seeds in their informal social networks. Some farmers were aware of the improved chickpea varieties like KWR 108 and Radhey that were released more than 20 years back.

\subsubsection{Different Varieties Accessed by Farmers After Membership}

Initiatives taken under TL-III projects in collaboration with the farmers' seed societies contributed to increased availability of quality seed of improved chickpea varieties to small holders in the region. Improved chickpea varieties (Kabuli: Shubhra, Ujjawal; Desi: JG 14, JAKI 9218, RVG 202, JG 16, RVG 203) were introduced in the seed system in the targeted districts. A total of 1524 smallholder farmers directly received seeds of above-mentioned improved chickpea varieties under the project as a result of activities of the platforms.

\subsubsection{Number of Non-Member Farmers Who Accessed Seed Through the Platform Members}

A total of 1524 partner farmers could directly receive the improved chickpea seed under the project activities through farmers seed societies. Encouraged with the improved productivity (from 0.78 to $1.19 \mathrm{t} / \mathrm{ha}$ ) of chickpea crop with introduced chickpea varieties, the area enhancement under the introduced improved varieties in the project villages was recorded to be 361 ha that accounted for 68 percent of the total cropped area (530 ha) during 2018-19. The highest area expansion (89\%) under improved chickpea varieties was witnessed in Hamirpur district. The expansion resulted due to farmer-to-farmer horizontal diffusion of varieties to 1788

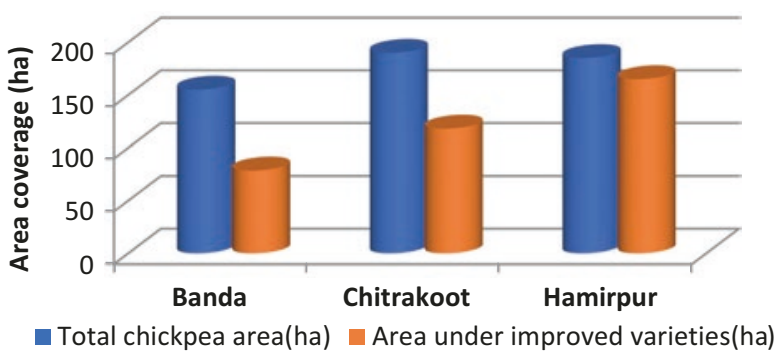

Fig. 8.1 Area coverage under introduced chickpea varieties in project villages in targeted districts. Source: Authors' calculations from data collected from project villages 
non-partner farmers from villages within $35 \mathrm{~km}$ radius around the project villages (Fig. 8.1).

\subsubsection{Acreage Grown to Improved Seed by Farmers Before Membership}

\subsubsection{Increase in Acreage Under Improved Seed by Farmers After Membership}

The member farmers of the farmers' seed societies who participated in the seed production programme have completely shifted (100\%) from non-descript varieties to the improved chickpea varieties introduced by the project interventions in project villages. The same trend was witnessed among the smallholder farmers who indirectly received the introduced chickpea seed from their informal networks. Reduced losses due to root rot incidences and higher productivity of chickpea crop due to improved varieties led to the mentioned shift.

\subsubsection{Achievements in the Areas of Access to New Markets and Finance Services and Other Services}

The partner farmers were linked to chickpea seed value chain and could earn a higher income collectively. The farmers received about $15-20 \%$ higher income by organized seed production than they earned for producing grain.

\subsubsection{Achievements in the Areas of Social Assets}

With the learnings in chickpea seed production, farmers' seed societies have started searching for partnership opportunities with National Seed Corporation, Agricultural Science Centres and other agencies located in their respective districts for seed production programmes of pulse crops. The members of the farmers' societies have gained recognition as reliable seed source in the region and this facilitated horizontal diffusion of chickpea seed in the region through informal social networks.

\subsubsection{Achievements in the Areas of Gender Equality and Youth}

Women involvement in seed systems related activities enhanced to $17 \%$ in 2018-19. This is a positive change from almost no involvement at the start of the project interventions. The continued persuasion of farmers' seed societies and TL-III project team gradually worked towards a better participation of women in the project activities. This insight lead to initiating women specific capacity building programmes, wherein women could interact freely. 


\subsubsection{Main Challenges Addressed for Youth}

The existing social taboo against involvement of women in activities facilitated by outside agency was a major challenge in the project activities. The social disapproval of women participation in these programmes also hindered the women involvement in project interventions initially but the situation has now significantly improved, and women participation is no longer seen as a taboo.

\subsubsection{Perceptions of Platform Performance}

The partner farmers were organized to form the village level farmers' seed societies as a part of interventions under TL-III project in the targeted districts of Banda, Hamirpur and Chitrakoot. These efforts provided the smallholder farmers their first experience of engaging in any formal seed platform. Many farmers were initially sceptical about joining the formal seed society as the membership was paid and it involved commitment and had financial provisions. With facilitation from project team and their successful experience in the initial year of operation, they gradually gained confidence to handle the seed production activities. In addition, based on the successful experience from engaging in chickpea seed production, the farmers' seed societies are keen on newer collaboration opportunities in seed production of other pulse crops.

\subsubsection{Sustainability of Multi-Stakeholder Platforms}

Efforts were made towards linking the farmers' seed societies with national and state level seed agencies operating in the region. These include organizations like Uttar Pradesh State Seed Development Agency, National Seed Corporation and Banda University of Agriculture and Technology, Banda, Uttar Pradesh State, India. Currently two farmers' seed societies operating in Hamirpur and Banda districts are starting to collaborate with the above-mentioned organizations.

\subsection{Reflections on the Process}

The farmers' seed societies formed could contribute towards strengthening the formal as well as informal seed system of chickpea in the region. The efforts helped farmers realize higher income (Rs 14,300 to Rs 31,160) from chickpea crop and sharing of associated risks. The successful experiences encouraged farmers' seed societies to expand their area of operation to other agricultural crops. The decentralized model of seed production at districts level evolved in the project contributed significantly towards improving the smallholder farmers' access to quality pulse seed in the targeted geographies. The model is especially relevant in context of 
constrained socio-economic and agro production situation in which chickpea is grown in the region.

\subsubsection{Brief Description of the Different Issues That Happened Over the Course of the Platform Activities' Implementation}

With limited prior interactions with public sector institutions, farmers were initially hesitant to the concept of organizing into farmers' seed society and collaborating in the process of strengthening seed system of chickpea. The cost involved towards receiving the membership of farmers' societies also influenced the farmer. However, with continued persuasion of the project team through series of discussion and meetings and matching of their need for quality seed of chickpea, farmers organized themselves into formal seed societies. The existing social dynamics influenced the process of group mobilization with incidences of preferences for a particular social group within villages.

The registered farmers' seed societies indirectly worked towards developing group bonding and facilitated farmer to-farmer exchange of information related to improved agricultural technologies and seed among the group members. The formal structure of the societies also facilitated member farmers in communicating their perceptions on chickpea production technologies with the project team and other agencies. The member farmers attached social prestige to their membership to the seed societies and to their contribution for improving the chickpea seed availability at village level.

\subsubsection{The Significance of Observed Achievements for the Livelihood of Different Stakeholder Involved}

Pulses assume special significance in the nutrition as well as economy of the farm households of the targeted geographies in India. The mentioned achievements had a direct impact on chickpea productivity and income levels of smallholder farmers through enhanced availability of quality seeds at village level.

\subsubsection{The Significance of Observed Achievements for the Communities at Whole}

The interventions contributed in strengthening the formal and informal seed system of chickpea in the region. A significant area expansion (68\%) under improved chickpea varieties was witnessed in the project villages. 


\subsection{Areas to Focus on in the Future}

Sustainability of the farmers' seed societies formed is a major challenge. The formal seed societies formed are still in the stage of evolving and growing, they need to be supported for becoming financially self-sustainable for some more years. Member farmers need handholding in record keeping and developing alternate income sources though appropriate linkages and collaborations.

The societies also need to be supported by providing them with some more opportunities to practice and perform the function of strengthening the chickpea seed system in the region.

Enhancing the coverage of the farmers' seed groups with respect to the agricultural crops, associated members and land under seed production needs focus in future efforts. Developing appropriate structural mechanisms for integration of the farmers' seed societies with public seed system may be explored for their sustainability.

\subsection{Lessons Learned}

\subsubsection{Highlights of Key Achievements}

- Partner farmers were organized into four registered farmers' seed societies in TL-III project districts in Bundelkhand region of India.

- The farmers' seed societies contributed towards strengthening the seed system of chickpea in the region by producing 21.8 tons of seed (FS/TL) of improved chickpea varieties (kabuli: Ujjawal, Shubhra; Desi: JG 14, JG 16 and JAKI 9218) and marketed it to formal seed chains.

- The interventions boosted chickpea productivity from 0.78 to $1.19 \mathrm{t} / \mathrm{ha}$ in the project villages.

- The efforts lead to area enhancement under the introduced improved chickpea varieties in the project villages to 361 ha that accounted for $68 \%$ of total cropped area (530 ha) during 2018-19.

\subsubsection{Major Lessons Learned}

- Developing decentralized seed system with involvement of farmers could contribute for creating huge impact on enhancing the access of smallholder farmers to quality seed of improved varieties.

- Due consideration to farmers preference for varietal options, based on their perception of appropriateness, is crucial for ensuring greater horizontal farmers-tofarmers diffusion of improved seed. 


\section{References}

Dixit GP, Srivastava AK, Singh NP (2019) Marching towards self-sufficiency in chickpea. Curr Sci 116(2):239-242

Srivastava AK, Dixit GP, Singh NP (2017) Assessing chickpea yield gaps in India: a tale of two decades. Outlook Agric 46(3):230-235

Open Access This chapter is licensed under the terms of the Creative Commons Attribution 4.0 International License (http://creativecommons.org/licenses/by/4.0/), which permits use, sharing, adaptation, distribution and reproduction in any medium or format, as long as you give appropriate credit to the original author(s) and the source, provide a link to the Creative Commons license and indicate if changes were made.

The images or other third party material in this chapter are included in the chapter's Creative Commons license, unless indicated otherwise in a credit line to the material. If material is not included in the chapter's Creative Commons license and your intended use is not permitted by statutory regulation or exceeds the permitted use, you will need to obtain permission directly from the copyright holder. 